\title{
Application of DSSAT Crop Simulation Model to Estimate Rice Yield in Keonjhar District of Odisha (India) under Changing Climatic Conditions
}

\author{
M. Ray ${ }^{*}$, P.K. Roul and A. Baliarsingh
}

Orissa University of Agriculture and Technology, Bhubaneswar, Odisha - 751003, India

*Corresponding author

\section{Keywords}

Climate change, DSSAT, Rice yield, Swarna

Article Info

Accepted:

07 March 2018

Available Online:

10 April 2018

\section{A B S T R A C T}

Changes of climate will be one of the deciding factors that affect for future food production in the world because crop growth is highly sensitive to any changes of climatic conditions. As the rice is staple food of Odisha, it is essential to identify the impacts of climate changes on State's rice production. This study was conducted to identify the yield and growth changes of the popular rice variety (Swarna) cultivated in Keonjhar district at kharif season. Effects of change in weather conditions on the yields of Swarna variety was assessed through sensitivity analysis using the Ceres rice model v 4.6 of the DSSAT modeling system. The model was validated using rice growth and development data during the 2015 cropping season. To simulate the rice yield DSSAT requires data sets of crop growth and management, daily weather data and soil data. Daily maximum and minimum temperatures and precipitation were collected from the weather station while daily solar radiation was generated using weatherman in the DSSAT shell. Crop management data were obtained from an experiment which was conducted in Keonjhar. The study revealed that increase in both maximum and minimum temperatures affects the grain yield. The results of the study therefore show that weather conditions in Keonjhar affect rice yield and should be taken into consideration to improve food security.

\section{Introduction}

Impacts of climate change on Agriculture will be one of the major deciding factors influencing the future food security of mankind on earth. Since rice is the staple food of India, it is essential to identify the impacts of climate change on rice yield to increase the country's rice production. Climatic factors such as temperature, rainfall, atmospheric $\mathrm{CO}_{2}$ and solar radiation are important parameters to rice production (Nyangau et al., 2014). The average daily maximum temperature and rainfall pattern will be changed as a result of increasing concentrations of $\mathrm{CO}_{2}$ and other greenhouse gases in atmosphere. These changes have become the most important considerations for rice production (Dharmarathna et al., 2011).

Increasing trend of daily maximum temperature may decrease the rice spikelet fertility, which affects for reduction of the yield while the increasing trend of atmospheric $\mathrm{CO}_{2}$ concentration could increase the rice yield (Dharmarathna et al., 2012). 
Keonjhar district is one of the rice cultivation districts in Odisha and have a good potential for rice cultivation. Most of the farmers in this area cultivate improved rice varieties but their yield is always lower than the potential yield due to the different level of management practices and the variation of climatic conditions. Yield gap can be increased in the future due to climate change especially if current agricultural practices are continued (Basak et al., 2012). Understanding rice production in relation to weather changes is of great importance to boost food productivity Conducting the field experiments for identify impacts of climate change on rice cultivation will take long time period.

DSSAT is a popular crop model that is used worldwide for modeling growth and yield of 30 different crops including rice under given soil and daily weather conditions. For future yield prediction it is required to calibrate and validate the DSSAT model with adjusting the cultivar genetic coefficients. Validated DSSAT model can be used to predict the future rice yields with future weather conditions and find the suitable adaptation measures for increase the yield (Jones et al., 2013). These tools can reduce the need for expensive and time-consuming field trials and could be used to analyze yield gaps in various crops including rice (Pathak et al., 2005). Therefore this study was conducted to identify the changes of rice yield and growth in Keonjhar district under changing climate using DSSAT model.

\section{Materials and Methods}

\section{Plant material}

Swarna rice variety was used in this study. This is because this variety is commonly grown variety in Keonjhar. The rice profile and management practices from nursery till harvest were monitored.

\section{Management practices}

Adopted and data collected: The crop management data (i.e., agronomic data) required by the model include planting date, planting density, row spacing, planting depth, fertilizer application dates, and amounts was recorded. The major crop management input data used in the model for simulations is shown in Table 1.

The following data were collected:

Daily weather data: Maximum and minimum air temperature, precipitation, and solar radiation.

Soil data: involved collection of set of input data on soil characteristics at $5 \mathrm{~cm}$ and $25 \mathrm{~cm}$ depths before and during the cropping season on soil classes, bulk density, organic carbon $(\%)$, sand silt clay (\%), soil texture, $\mathrm{pH}$ of soil in water, organic carbon, cation exchange capacity, total nitrogen, potassium, and phosphorus,

Management practices: plant density, planting date, irrigation, weeding, row spacing, sowing depth, and nitrogen fertilization,

Plant profile data: data related to date of sowing, date of emergence, date of floral initiation, date of synthesis, date of physiological maturity, panicle initiation date (when $50 \%$ of the crop had reached those stages) plant population, plant height, grain weight, and grain yield per area of production, Latitude of production area to evaluate day length during the cropping season.

The following six input files were created to run the model:

Weather file with annual daily solar radiation, maximum air temperature, minimum air 
temperature, and precipitation,

Soil file with soil properties under study,

Rice management file

Experimental data file with measured data,

Genetic coefficients file: The cultivar coefficient was determined with thermal time from emergence to the end of juvenile stage $(\mathrm{P} 1)$, rate of photo induction $(\mathrm{P} 2 \mathrm{R})$, optimum photoperiod (P2), thermal time for grain filling (P5), conversion efficiency from sunlight to assimilates (G1), tillering rate (TR), and grain size (G2).

\section{Data analysis}

The CERES rice model version 4.6 of the DSSAT modeling system which is an advanced physiologically based rice crop growth simulation model was used to predict rice (Swarna) growth, development, and response to various climatic conditions. This was through determination of duration of growth stages, dry matter production and partitioning, root system dynamics, effect of soil water and soil nitrogen contents on photosynthesis, carbon balance, and water balance (Ritchie et al., 1986), followed by sensitivity analysis to assess the effects of change in weather conditions on Swarna grain yield.

\section{Model calibration and validation}

The model was calibrated experimental data for Swarna variety of rice for the main cropping season 2015 as reported by Ndiiri et al., 2012. The model was validated using the rice growth and development data, during the cropping season July to Nov 2015. This was done by comparing the observed results with simulated yield. In this study, combination of graphical, tabular, and statistical analysis was applied. Model performance evaluation was presented by the absolute Root Mean Square Error (RMSE) This characteristic is common tools to test the goodness of fit of simulation models. The RMSE between the simulated and observed values for a data set with measured points is defined as

$$
\begin{gathered}
\text { RMSE } \left.=\left[\sum_{i=1}^{n} \frac{(\mathrm{Si}-\mathrm{Ob})^{2}}{n}\right)\right]^{0.5} \\
\operatorname{RMSE}_{n}=100 \frac{\left.\left[\sum_{i=1}^{n}(\mathrm{Si}-\mathrm{Ob})^{2} / n\right)\right]^{0.5}}{\mathrm{Ob}_{\text {avg }}},
\end{gathered}
$$

Where $\mathrm{Si}=$ simulated value, $\mathrm{Ob}=$ observed value, and $=$ number of observations.

The observed data points may be from one treatment or multiple treatments ( $\mathrm{Ma}$ and Selim, 2005). Goodness was evaluated visually and by computing index of agreement. The index of agreement is defined by Ahiya et al., (2002) as shown in (3).

The computed values of RMSE and value determine the degree of agreement between the predicted values with their respective observed values, and a low RMSE value and a value that approaches 1 are desirable.

$$
D=1-\frac{\sum_{i=1}^{n}(\mathrm{Si}-\mathrm{Ob})^{2}}{\left.\sum_{i=1}^{n}\left(\mid \mathrm{Si}-O b_{\text {avg }}\right)\left|O b i-O b_{\text {avg }}\right|\right)^{2}} .
$$

Normalized RMSE (RMSEn) was used to give a measure $(\%)$ of the relative difference of simulated versus observed data. The simulation was considered excellent with a normalized RMSE less than $10 \%$, good if the normalized RMSE was greater than 10 and less than $20 \%$, fair if the normalized RMSE was greater than $20 \%$ and less than $30 \%$, and poor if the normalized RMSE was greater than 30\% (Loague and Green., 1991). 


\section{Results and Discussion}

Weather conditions during the cropping season

According to Hay and Walker, 1989 the primary atmospheric variables that impact on crop growth are solar radiation, air temperature, humidity, and precipitation. They mentioned that extreme weather at critical periods of a crop's development can have large effects on its productivity and yield.

The climate of Keonjhar is governed by seasonal monsoon rainfall patterns. During 2015, maximum and minimum temperatures, rainfall, and solar radiation varied as shown in Figure 1. During the cropping season, the mean maximum temperature $(\max )$ and minimum temperature $(\min )$ were $31.6^{\circ} \mathrm{C}$ and $19.4^{\circ} \mathrm{C}$, respectively. Mean solar radiation was $18.7 \mathrm{MJ} / \mathrm{m}^{2}$ while total precipitation was $1183.9 \mathrm{~mm}$.

B. Genetic Coefficients The value for the cultivar coefficients that determine vegetative $(\mathrm{P} 1, \mathrm{P} 5, \mathrm{P} 2 \mathrm{O}$, and $\mathrm{P} 2 \mathrm{R})$ and reproductive ( $\mathrm{G} 1$, G2, G3, and G4) growth and development for Swarna variety of rice is presented in Table 2. The cultivar coefficient P1 defines the time from seedling emergence to the end of juvenile phase (GDD). The coefficient P2O is the extent at which the development occurs at a maximum rate. The coefficient $\mathrm{P} 2 \mathrm{R}$ is the extent to which phasic development from vegetative to panicle initiation was delayed for each hour increase in photoperiod above P2O. The coefficient P5 is the time from grain filling to physical maturity. The coefficient. G1 defines the maximum spikelet number coefficient. The cultivar coefficient G2 is the maximum possible single grain size under stress free conditions. The coefficient G3 defines the scalar vegetative growth coefficient for tillering. The cultivar coefficient G4 defines the temperature tolerance scalar coefficient. Genetic coefficients are sets of parameters that describe the genotype and environmental interactions (IBSNAT, 1993). They summarize quantitatively how a particular cultivar responds to environmental factors.

\section{Main growth and development variables}

Table 3 shows the mean simulated and observed main growth and development variables.

\section{Model validation}

The model was validated using observed growth and phenological data collected during the 2015 cropping season. A good match was obtained between observed and simulated grain yield with a RMSE of $0.817 \mathrm{t} / \mathrm{ha}$ and a normalized RMSE (RMSEn) of $14.943 \%$. An index of agreement for grain yield closer to 1 $(0.869)$ also revealed that the model performed well in predicting the yield. The regression analysis gave a coefficient of determination $\left(R^{2}\right)$ value of 0.778 . In general, the results from the model validation indicate that CERES rice version 4.6 was able to predict growth and development for Swarna variety in a good manner and therefore can be applied as a study tool.

The -stat of a "good" model should approach unity and the RMSE approach zero. The RMSE is considered as the "best" overall measure of model performance as it summarizes the mean difference in the units of observed and predicted values (Willmot, 1982 and Toit and Toit, 2003).

\section{Sensitivity analysis on climatic adaptations}

Temperature regime greatly influences not only the growth duration but also the growth pattern of the rice plant. 
Table.1 Crop management data used in the model

\begin{tabular}{|c|}
\hline Serial/number \\
\hline 1 \\
\hline 2 \\
\hline 3 \\
\hline 4 \\
\hline 5 \\
\hline 6 \\
\hline 7 \\
\hline 8 \\
\hline 9 \\
\hline
\end{tabular}

Simulation parameter

Planting method

Transplanting date

Planting distribution

Row spacing

Planting depth

Transplanting age

Plant per hill

Plants per $\mathrm{m}^{2}$

Fertilizer application

Basal

21 DAP

45 DAP
Nursery

August 20, 2015

Hill

$20 \mathrm{~cm}$ by $10 \mathrm{~cm}$

$2 \mathrm{~cm}$

21days

1

16

\section{$20 \mathrm{~kg} / \mathrm{ha}$}

$40 \mathrm{~kg} / \mathrm{ha}$

$20 \mathrm{~kg} / \mathrm{ha}$

Table.2 Genetic coefficients for Swarna

\begin{tabular}{|c|c|c|c|c|c|c|c|}
\hline P1( ${ }^{0}$ C-days $)$ & $\begin{array}{c}\text { P2R }\left({ }^{0} \mathrm{C}-\right. \\
\text { days })\end{array}$ & P5 $\left({ }^{0}\right.$ C-days $)$ & P2O(h) & G1(no. & G2(g) & G3 & G4 \\
\hline 620 & 180 & 490 & 11.8 & 70 & 0.02 & 1 & 1 \\
\hline
\end{tabular}

Satapathy et al., 2014

Table.3 Main growth and development variables

\begin{tabular}{|l|}
\multicolumn{1}{|c|}{ Variable } \\
\hline Anthesis \\
\hline Physiological maturity (dap) \\
\hline Yield at harvest maturity (t/ha) \\
\hline Unit weight at maturity (g) \\
\hline
\end{tabular}

\begin{tabular}{|c|c|}
\hline Simulated & Observed \\
\hline 77 & 79 \\
\hline 115 & 111 \\
\hline 6.131 & 6.022 \\
\hline 0.025 & 0.024 \\
\hline
\end{tabular}

Table.4 Effects of plus maximum and minimum temperatures on simulated Swarna yield grain

\begin{tabular}{|c|}
\hline $\begin{array}{c}\text { Plus } \\
\text { temperature }\left({ }^{0} \mathrm{C}\right)\end{array}$ \\
\hline+1 \\
\hline+2 \\
\hline+3 \\
\hline+4 \\
\hline+5 \\
\hline
\end{tabular}

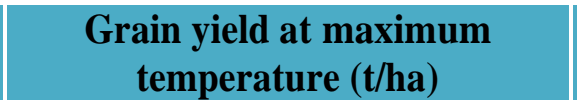

5.712

5.168

4.837

4.056

3.711
Grain yield at minimum temperature (t/ha)

\begin{tabular}{|c|c|}
\hline 5.712 & 5.621 \\
\hline 5.168 & 5.163 \\
\hline 4.837 & 4.385 \\
\hline 4.056 & - \\
\hline 3.711 & - \\
\hline
\end{tabular}


Table.5 Critical temperatures for the development of rice plant at different growth stages

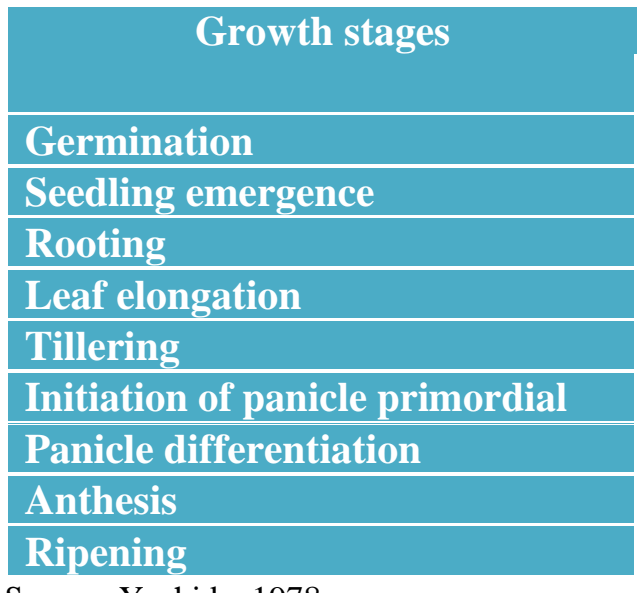

\begin{tabular}{|c|c|c|}
\hline \multicolumn{3}{|c|}{ Critical temperature $\left({ }^{0} \mathrm{C}\right)$} \\
\hline Low & Oligh & Optimum \\
\hline $16-19$ & 45 & $18-40$ \\
\hline 12 & 35 & $25-30$ \\
\hline 16 & 35 & $25-28$ \\
\hline $7-12$ & 45 & 31 \\
\hline $9-16$ & 33 & $25-31$ \\
\hline 15 & - & - \\
\hline $15-20$ & 30 & - \\
\hline 22 & $35-36$ & 33 \\
\hline $12-18$ & $>30$ & $20-29$ \\
\hline
\end{tabular}

Source: Yoshida, 1978

Fig.1 Keonjhar weather for 2015

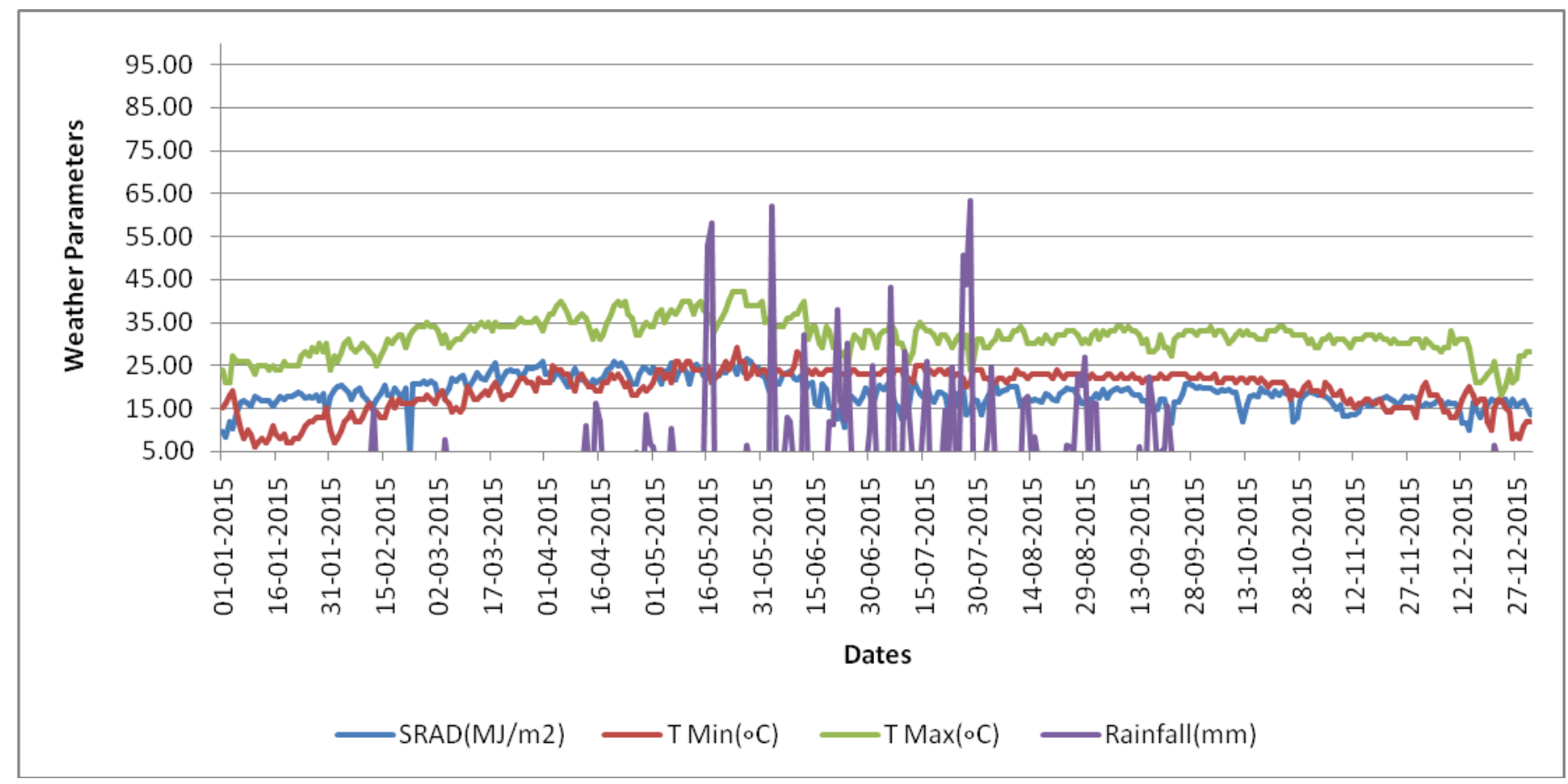

During the growing season, the mean temperature, the maximum and minimum temperature, rainfall distribution pattern, and diurnal changes, or a combination of these, may be highly correlated with grain yields (Mooman and Vergara., 1965). Effects of increase in temperature on Swarna rice grain yield was assessed by increasing the maximum and minimum temperatures by +1 , $+2,+3,+4$, and +5 followed by subsequent simulations.

The simulated results in Table 4 shows that increase in both maximum and minimum temperature led to a decrease in grain yield. As compared to maximum temperature, 
increase in minimum temperature had more pronounced negative impacts on Swarna yield. This more pronounced negative impact of minimum temperature on rice yield could be explained by increased respiration losses during the vegetative phase (Peng et al., 2004) and reduced grain-filling duration and endosperm cell size during the ripening phase (Morita et al., 2005).

Temperature regimes greatly influence not only the growth duration, but also the growth pattern and the productivity of rice crops. The critical temperatures for the development of the rice plant at different growth phases are highlighted by Yoshida (1978) as shown in Table 5 .

Other studies on rice productivity under global warming also suggest that the productivity of rice and other tropical crops will decrease as global temperature increases. Mohandrass et al., (1995), using the Hadleycoupled model, predicted a yield decrease of 14.5 percent for summer rice crops across nine experiment stations in India in 2005. Peng et al., (2004) reported that the yield of dry-season rice crops in the Philippines decreased by as much as 15 percent for each $1^{\circ} \mathrm{C}$ increase in the growing season mean temperature. In Bangladesh, the impact of climate change on high yield rice varieties was studied by Karim et al., (1994) using the CERES rice model and several scenarios and sensitivity analysis. They found that high temperatures reduced rice yields in all seasons in most arid locations.

Temperature is considered to be one of the dominant factors that affect the growth and yield of rice. Each phase has its low and high temperature thresholds. The effect of temperature on vegetative growth of rice plants was reviewed in relation to germination, early growth, rooting, tillering, and the critical temperature common for different physiological plant properties that were $0-3^{\circ} \mathrm{C}, 15-18^{\circ} \mathrm{C}, 30-33^{\circ} \mathrm{C}$, and $45-48^{\circ} \mathrm{C}$, respectively (Nishiyama., 1976). Low temperature in early growth stages retards the development of seedling and dry matter production (Yoshida, 1978). In tropical regions, the temperature increase due to the climate change is probably near or above the optimum temperature range for the physiological activities of rice (Hogan et al., 1991). Such warming will thus reduce rice growth. In addition, higher temperatures will cause spikelet sterility owing to heat injury during panicle emergence (Satake and Yoshida., 1978).

Changes in mean temperatures can shorten the time to maturity of a crop, thus reducing yield. Hardacre and Turnbull, 1986 state that temperature affects the duration of crop growth and consequently the time during which incident radiation can be intercepted and transformed to dry matter. Temperature also affects final leaf number (Stevenson and Goodman., 1972) and leaf canopy development (Tollenaar et al., 1979; Thiagarajah and Hunt., 1982). Which defined crop leaf area index, thereby determining the proportion of the incident radiation intercepted (Muchon and Carberry, 1993) by the crop and accumulation of dry matter. At the same time, while using ORYZA1 and INFOCROP rice simulation models at the current $\mathrm{CO}_{2}$ levels studies have also shown that even a few days of temperature above a threshold value, if coincident with anthesis, can significantly reduce yield, through affecting subsequent reproductive processes (Wheeler et al., 2000). Generally, the effect of increasing temperature above the tolerance limit on rice potential production is generally negative. Temperature beyond the optimum level reduces the photosynthesis, increase the respiration and shorten the vegetation and grain-filling periods. Rice yield is negatively correlated with high $\left(>35{ }^{\circ} \mathrm{C}\right)$ temperature 
during the reproductive phase (Satake and Yoshida, 1978).

Weather changes affect Swarna yield in Keonjhar. Increase in maximum and minimum temperatures beyond optimum temperatures for rice production led to a decrease in yield and minimum temperature changes had more profound negative impacts as compared to maximum temperature changes. Therefore to improve rice production in Keonjhar, proper understanding of the prevailing weather conditions and regular monitoring is necessary.

\section{References}

Ahuja, L.R., L. Ma, and T. A. Howell., 2002. Agricultural System Models in Field Research and Technology Transfer, CRC Press, New York, NY, USA.

Basak JK, Ali MA, Biswas JK, Islam MN., 2012. Assessment of the effect of climate change on Boro rice yield and yield gaps using DSSAT model. Bangladesh Rice Journal 16, 67-75.

Dharmarathna WRSS, Weerakoon SB, Herath S, Rathnayaka UR, Weerakoon WMW., 2011. Application of Decision Support System for Agrotechnology Transfer (DSSAT) model to optimize irrigated paddy cultivation under changing hydro climate, Annual transactions of Institutions of Engineers, Sri Lanka. 207-211.

Dharmarathna WRSS, Weerakoon SB, Rathnayaka UR, Herath S., 2012. Variation of Irrigated rice yield under the climate change scenarios, SAITM research symposium on Engineering Advancements. Pp. 31-34.

Hardacre, A.K., and H. I. Turnbull., 1986. The growth and develop-ment of maize (Zea mays L.) at five temperatures. Annuals of Botany. 58, 779-787.

Hay, R.K., and A. J. Walker., 1989. An Introduction to the Physiology of Crop Yield, Longman Scientific and Technical, Harlow Essex, UK.

Hogan, K.P., A. P. Smith, and L. H. Ziska., 1991.
Potential effects of elevated $\mathrm{CO}_{2}$ and changes in temperature on tropical plants. Plant, Cell and Environment. 14(8), 763778.

IBSNAT, The IBNET Decade, Department of Agronomy and Soil Science, College of Tropical Agriculture and Human Resources, University of Hawaii, Honolulu, Hawaii, USA,.

Jones JW, Hoogenboom G, Porter CH, Boote KJ, Batchelor WD, Hunt LA, Wilkens PW, Singh U, Gijsman AJ, Ritchie JT., 2003. The DSSAT cropping system model. European Journal of Agronomy. xx, 235265

Karim, Z., M. Ahmed, S. G. Hussain, and K. B. Rashid, "Impact of climate change on the production of modern rice in Bangladesh," in Implications of Climate Change for Interna-tional Agriculture: Crop Modeling Study, C. Rosenzweig and A. Iglesias, Eds., EPA 230-B-94-003, US Environmental Protection Agency, Washington, DC, USA, 1994.

Loague, K., and R. E. Green., 1991. Statistical and graphical methods for evaluating solute transport models: overview and application. Journal of Contaminant Hydrology. 7(1-2), $51-73$.

Ma, L., and H. M. Selim., 1994. Predicting atrazine adsorption-desorption in soils: a modified second-order kinetic model. Water Resources Research. 30(2), 447-456.

Mohandrass S., A. A. Kareem, T. B. Ranganathan, and S. Jeyaraman, "Rice production in India under the current and future climate," in Modeling the Impact of Climate: Change on Rice Production in Asia, B. Mathews, M. J. Krof f, D. Bachelet, and H. H. van Laar, Eds., pp. 165-181, CABI, Wallingford, UK, 1995

Moomaw, J.C., and B. S. Vergara., 1965.The environment of tropical rice production.

Morita, S., J. Yonemaru, and J. Takanashi., 2005. Grain growth and endosperm cell size under high night temperatures in rice (Oryza sativa L.). Annals of Botany. 95(4), 695-701.

Muchow, R.C., and P. S. Carberry, "Designing improved plant types for the semiarid tropics: agronomists view points," in 
Systems Approaches for Agricultural Development, F. W. T. P. de Vries, Ed., pp. 37-61, Kluwer Academic Press, Dordrecht, The Netherlands, 1993.

Ndiiri, J.A., B. M. Mati, P. G. Home, B. J. Odongo, and N. Uphoff., 2012. Comparison of water saving of paddy rice under system of rice Intensification (SRI) growing in Mwea, Kenya. International Journal of Current Research and Review. vol. 4, no. 6,

Nishiyama, I., Climate and Rice, IRR1, 1976.

Nyangau WO, Mati BM, Kalamwa K, Wanjogu RK, Kiplagat LK., 2014. Estimating rice yield under changing weather conditions in Kenya using CERES rice model. International Journal of Agronomy. vol 2014.

Pathak, H., C. Li, and R. Wassmann., 2005. Greenhouse gas emissions from Indian rice fields: calibration and upscaling using the DNDC model. Biogeosciences Discussions. 2(1). 77- 102.

Peng, S., J. Huang, J. E. Sheehy. "Rice yield decline with higher night temperature from global warming," in Rice Integrated Crop Management: Towards a Ricecheck System in the Philippines, E. D. Redona, A. P. Castro, and G. P. Llanto, Eds., pp. 46-56, PhilRice, Nueva Ecija, Philippines, 2004.

Ritchie, J.T., E. C. Alocilja, U. Singh, and G. Uehara., "IBSNAT and the CERES-rice model," in Weather and Rice: Proceedings of the International Workshop on the Impact of Weather Parameters on Growth and Yield of Rice, 7-10 April 1986, pp. 271-281, International Rice Research Institute, Manila, Philippines,

Satake, T., and S. Yoshida., 1978. High temperature-induced sterility in indica rice at flowering. Japanese Journal of Crop
Science. 47(1), 6-17.

Stevenson, J.C., and M. M. Goodman., 1972. Ecology of exotic races of maize: 1. Leaf number and tillering of 16 races under four temperatures and two photoperiods. Crop Science, 12 (6), 864-868.

Sushree Sagarika Satapathy, Dillip Kumar Swain, Srikantha Herath., 2014. Field experiments and simulation to evaluate rice cultivar adaptation to elevated carbon dioxide and temperature in sub-tropical India. European Journal of Agronomy. 54, 21-33.

Thiagarajah, M.R., and L. A. Hunt., 1982. Effects of temperature on leaf growth in corn (Zea mays L.). Cannadian Journal of Botany. 60(9) 1647-1652.

Toit, A.S., and D. L. Toit, 2003. Short description of the model statistical package and weather analogue program. Report, University of Florida, Gainesville, Fla, USA.

Tollenaar, M., T. B. Daynard, and R. B. Hunter., 1979. Effect of temperature on rate of leaf appearance and flowering date in maize. Crop Science. 19(3), 363-366.

Wheeler, T.R., P. Q. Craufurd, R. H. Ellis, J. R. Porter, and P. V. V. Prasad., 2000. Temperature variability and the yield of annual crops. Agriculture, Ecosystems and Environment. 82(1-3), 159-167.

Willmott, C.J., 1982. Some comments on the evaluation of model performance. Bulletin of the American Meteorological Society, 63(11), 1309-1313.

Yoshida, S., "Tropical climate and its influence on rice," IRRI Research Paper Series 20, IRRI, Los Banos, Philippines, 1978.

\section{How to cite this article:}

Ray, M., P.K. Roul and Baliarsingh, A. 2018. Application of DSSAT Crop Simulation Model to Estimate Rice Yield in Keonjhar District of Odisha (India) under Changing Climatic Conditions. Int.J.Curr.Microbiol.App.Sci. 7(04): 659-667.

doi: https://doi.org/10.20546/ijcmas.2018.704.075 